\title{
Teacher's Personality and Classroom Management of Tertiary Institutions in Nigeria: The Issues and Perspectives
}

Andabai, Priye W.

\author{
Department of Finance and Accountancy, \\ Niger Delta University, Bayelsa State.,Nigeria \\ Basuo, Bio K. \\ Department of Business Administration, \\ Niger Delta University, Bayelsa State, Nigeria
}

\section{Doi:10.5901/jesr.2013.v3n6p113}

\begin{abstract}
The basis of any purposeful school programme depends on effective and efficient organization and intelligent planning. Consequently, so many researchers have written on the qualities of a teacher, therefore, the study evaluates the impact of teacher's personality on classroom management in tertiary institutions. Data was sourced from questionnaire and analyzed using mean and standard deviation. The decision rule used for the study was a modified scale which states that any mean below 2.5 is low, not significant or negative while any means above 2.5 is high, significant or positive. The study reveals that the extent which teacher's personality affects students' motivation is low. There is also a positive relationship between teacher personality and learning. Teacher's personality does not affect classroom discipline but does affect teacher-student relationship. Therefore the study recommended that Teacher's personality should be one of the criteria in the employment of teachers by employers of such labour apart from educational qualification and Personality influences. The behaviour of the teacher should be checked in diverse ways, such as interaction with students, teaching methods, and learning experience chosen. The teacher should ensure that his personality speaks positively to the students in encouraging them to learn in tertiary institutions in Nigeria.
\end{abstract}

Keywords: Teacher's, Personality, Classroom Management, Issues and Challenges

\section{Introduction}

According to Koko (2003), one of the indicators of an effective and efficient business educator is the ability to channel student's behaviour towards set educational goals and objectives. Thompson (2009) posits that, such educator must be an expert in his professional area as well as a good classroom manger thus she said, every teacher must exhibit acceptable leadership behaviour and mastery of the chosen subject area to command the recognition and acceptance of the students. Stipek (1998) maintained that, without a cordial teacher-student relationship, there will be no effective teaching and learning. When it comes to classroom setting, the teacher is seen as a leader and leadership is a means of direction and a product of interaction. Jacob (2009) confirmed that, it is seen as an interpersonal influence exercise in situations and directed through the communication process towards the attainment of specific goal or goals.

According to Nnamdi (2000), the leader is characterized by a strong drive for responsibility and task completion, vigor and persistence in pursuit of goals, venture some and originality in problem solving, drive to exercise initiative in social situations, self-confidence and a sense of 
personal identity, willingness to accept consequences of decision and action, readiness to absorb interpersonal stress, willingness to tolerate frustration and delay, ability to influence other persons' behaviour, and capacity to structure social interaction systems to the purpose at hand. Lew (2009) concluded that, the above summary shows the influence of personality qualities or traits on leadership. Coats 2009 agreed that, the trait approach also he said question the validity of training of individuals to assume leadership positions. He said for leadership training to be of any value, only individuals with inherent leadership traits should be given such training opportunities. This simply means only persons who have the leadership trait of a teacher should take up the teaching profession.

\section{Conceptual Framework}

Lew (2009) writing on teaching and teacher, defined a teacher as a person engaged in interactive behaviour with one or more students for the purpose of effecting a change in the students. The change, be it in any of the three domains of learning: cognitive, psychomotor and affective. According to McNail (1973), the teacher's personality is therefore, directly and individually related to learning and teaching in the affective, cognitive and psychomotor domains. Callahan (2002) sees personality as the dynamic organization of those traits and characteristic patterns of behaviour that are unique to the individual. Murray (2007) said personality influences the behaviours of the teacher in diverse ways: interaction with students, teaching methods selected, and learning experiences chosen as such the effective use of a teacher's personality essential in conducting instructional activities. According to I gwe (2000), most studies citing Argyris,

Hornadey and Bunker (2009) based on trait such as alertness, integrity; originality and self confidence are associated with effective leadership. Citing Stogdill (2001), he said a person does not become a leader by virtue of the possession of some combination of trait but the pattern of personal characteristics of the teacher which must bear some relevant relationship with the students. Lew (2009) puts; teacher's personality is a crucial factor in arranging the conditions of the learner's environment for effective teaching. No man can be a good teacher unless he has feelings of warm affection towards his pupils and a genuine desire to impart to them what he himself believes to be of value. Bertrand Russell. Lew (2009) pointed out that, many of the positive characteristics of successful teachers discovered in previous research efforts seem to be in line with Maslow's conceptualization of the self-actualizing person. Whom he sees as a fully functioning, psychologically healthy individual possessing such attributes as acceptance, spontaneity, autonomy, democratic nature, and creativeness. He stressed that for Maslow, the self-actualizing person is indeed the most effective teacher. This hypothesis was supported by the findings of empirical studies conducted by Murray and Dandes in Lew (2009). Coats (1997) in Lew (2009) did a factor analysis of student responses on their perception of their teachers. It was found that a factor labeled teacher 'charisma' accounted for $61.5 \%$ of the variance in test items. It was concluded that teacher charisma probably a significant factor of teacher effectiveness which is a personality trait.

\section{Issues and Challenges}

Koko (2001) stated that, personality in the context of the classroom means the projection of ones social self which reflect: (i) the teachers' ability to inspire enthusiasm. (ii) The teachers' interest, or affection in others by means of influence. (iii) the teachers' principles: that is belief, attitude value or standard. It also reflects his ethics (morals or standard of behaviour). (iv) The teachers' behaviour as a role model. According to him, teachers are encouraged to work towards the attainment of effective classroom management through interpersonal relationships and to achieve harmony and spirit de corps in the classroom. The teacher must exhibit an understanding of the unique structure of students. Conversely she said, when a teacher disregards his/her students by way of negative interpersonal relationship, the outcome will be disruption and crisis in the learning 
environment. According to Awotua-Efebo (2007) citing Yelon and Weinstein said there are five important areas in which the behaviour of the teacher can influence group dynamics in the classroom. They are: (i) Classroom structure: co-operative or competitive. (ii) The nature of leadership: participative, directive or permissive. (iii) Compatibility of norms: the goals of students and those of the teacher. (iv)Interpersonal relationships: pattern of communication and attraction with the group. (v) Subgroup within the classroom, group size and composition.

Koko (2002) stressed that, the belief teachers have about teaching and learning and the nature of the expectations they hold for students also exert a powerful influence. As Stipek (1988) said, to a very large degree, students expect to learn if their teachers expect them to learn, because all human behaviour arises in response to some forms of internal (physiological) or external (environmental) stimulation. These behaviours are purposeful or goal directed, or is the result of the arousal of certain motives. Thus motivation can be defined as the process of activating, maintaining and directing behaviour toward a particular goal. Awotua-Efebo (2007) pointed out that students who are motivated and involved in the learning process tend to do well in their academic work. This implies that they are not likely to misbehave in the classroom. Koko (2001) pointed that one of the indicators of an effective and efficient business educator is the ability to channel students' behaviour towards set educational goals and objectives as such; the teacher she said has to be an expert in his professional area s well as a good classroom manager. Knowledge of the subject does not really mean knowing history, mathematics or English, but knowing what to teach and how to teach it, knowing who you are teaching and how to teach them. Knowing who they are and how to motivate them above all, knowing when to teach and where to teach it.

\section{Methodology}

Data was sourced from primary sources and they were collated and analyzed using mean and standard deviation. The decision rule used was a modified scale, which means that any mean below 2.5 is rejected while any mean above 2.5 is accepted. The research questions formulated were as follows: (i) to what extent does teacher personality affect student motivation? (ii) What is the relationship between teacher personality and learning? (iii) To what extent does teacher personality affect classroom discipline? (iv) Does teacher personality affect student-teacher relationship?

\section{Analysis and Results}

The analyses of data obtained from the study were presented in the following tables:

Table 1: To what extent does teacher's personality affects student's motivation?

\begin{tabular}{|c|l|c|c|c|c|}
\hline $\mathbf{S / n}$ & \multicolumn{1}{|c|}{ Items } & $\begin{array}{c}\text { Total } \\
\text { response }\end{array}$ & Mean & $\begin{array}{c}\text { Standard } \\
\text { deviation }\end{array}$ & Remarks \\
\hline 1 & $\begin{array}{l}\text { I like the subject because I like the teacher } \\
\text { and the way he/she presents the subject }\end{array}$ & 87 & 2.46 & 1.09 & Low \\
\hline 2 & $\begin{array}{l}\text { We do want to learn the subject but the } \\
\text { class is always boring }\end{array}$ & 76 & 2.77 & 1.05 & High \\
\hline 3 & $\begin{array}{l}\text { I dislike the subject due to the way teacher } \\
\text { talks to us in class }\end{array}$ & 64 & 2.73 & 1.22 & High \\
\hline 4 & $\begin{array}{l}\text { My teacher is an understanding person that } \\
\text { is why I like the subject }\end{array}$ & 62 & 2.25 & 1.16 & Low \\
\hline 5 & Our teacher makes the class very interesting & 629 & 2.48 & 1.05 & Low \\
\hline
\end{tabular}

Source: Survey data 2013. Mean $(x)=2.54$, Remark $=$ High 
Table 1 shows that, the mean and standard deviation score of item one ( $x=2.46, S D=1.09)$, item four $(x=2.25, S D=1.16)$, and item five $(x=2.48, S D=1.05)$ which means that, the extent which teacher's personality affect students' motivation is low. The table also shows that the mean and standard deviation score of item two $(x=2.77, S D=1.05)$, and item three $(x=2.73, S D=$ 1.22).

Table 2: What is the Extent of relationship between teacher personality and learning?

\begin{tabular}{|c|l|c|c|c|c|}
\hline S/n & \multicolumn{1}{|c|}{ Items } & Total response & Mean & Standard deviation & Remarks \\
\hline 1 & Teachers personality & 70 & 2.50 & 1.12 & Positive \\
\hline 2 & Learning & 72 & 2.66 & 1.12 & Positive \\
\hline
\end{tabular}

Source: Survey data 2013. Mean $(x)=2.58$, Remark $=$ Positive

Table 2 shows that, the mean and standard deviation score of teacher personality $(x=2.50, S D=$ $1.12)$ and learning $(x=2.66, S D=1.12)$ this indicates that there is a positive relationship between teacher personality and learning as reflected in the mean $(x)=2.58$ indicate that, there is a positive relationship between teacher personality and learning in tertiary institutions.

Table 3: Does teacher's personality affects classroom management?

\begin{tabular}{|c|l|c|c|c|c|}
\hline $\mathbf{S / n}$ & \multicolumn{1}{|c|}{ Items } & $\begin{array}{c}\text { Total } \\
\text { response }\end{array}$ & Mean & $\begin{array}{c}\text { Standard } \\
\text { deviation }\end{array}$ & Remarks \\
\hline 1 & $\begin{array}{l}\text { Our teacher does not permit noisemaking } \\
\text { when he/she is teaching }\end{array}$ & 69 & 2.48 & 1.11 & Low \\
\hline 2 & $\begin{array}{l}\text { I like the because we could relate freely } \\
\text { with our teacher }\end{array}$ & 67 & 2.40 & 1.06 & Low \\
\hline 3 & $\begin{array}{l}\text { Our teacher is a good role model to us in } \\
\text { and out of the classroom }\end{array}$ & 66 & 2.39 & 1.18 & Low \\
\hline 4 & $\begin{array}{l}\text { I like out teacher because he/she is fair } \\
\text { and treats everyone equal in class }\end{array}$ & 70 & 2.51 & 1.23 & High \\
\hline 5 & $\begin{array}{l}\text { Our teacher always wants us to pay } \\
\text { attention when he/she is teaching. }\end{array}$ & 60 & 2.42 & 1.16 & Low \\
\hline
\end{tabular}

Source: Survey data 2013. Mean $(x)=2.44$ Remark $=$ low

Table 3 shows that, the mean and standard deviation score of item one $(x=2.48, S D=1.11)$, item two $(x=2.40, S D=1.06)$, and item three $(x=2.39, S D=1.18)$ and item five $(x=2.42, S D$ $=1.16)$, this indicates that, the extent which teacher's personality affect classroom discipline is low. The table also showed that, the mean and standard deviation scores of item four are $(x=2.51, S D$ $=1.23$ ) on the other hand a high extent teacher's personality affect classroom discipline.

Table 4: How does teacher's personality affects student-teacher relationship?

\begin{tabular}{|c|l|c|c|c|c|}
\hline $\mathbf{S} / \mathbf{n}$ & \multicolumn{1}{|c|}{ Items } & $\begin{array}{c}\text { Total } \\
\text { response }\end{array}$ & Mean & $\begin{array}{c}\text { Standard } \\
\text { deviation }\end{array}$ & Remarks \\
\hline 1 & $\begin{array}{l}\text { Our teacher takes extra time to explain, to } \\
\text { make sure we all understood the course }\end{array}$ & 69 & 2.242 & 1.14 & Low \\
\hline & $\begin{array}{l}\text { We don't pay attention to the teacher } \\
\text { because of the way he/she dresses to the } \\
\text { classroom }\end{array}$ & 70 & 2.52 & 1.05 & High \\
\hline 3 & $\begin{array}{l}\text { We respect our teacher because of the way } \\
\text { he/she carries him/herself }\end{array}$ & 66 & 2.39 & 1.18 & Low \\
\hline
\end{tabular}

Source: Survey data 2013. Mean $(x)=2.50$, Remark $=$ High 
Table 4 shows that, the mean and standard deviation score of item one $(x=2.42, S D=1.14)$, this also means that, the extent which teacher's personality affect teacher-student relationship is low. The table also shows that the mean and standard deviation scores of item two are $(x=2.52, \mathrm{SD}=$ $1.05)$ and item three $(x=2.55, \mathrm{SD}=1.17)$

\section{Conclusion and Recommendations}

The study revealed that the extent which teacher's personality affects students' motivation is low. There is also a positive relationship between teacher personality and learning. And teacher's personality does not affect classroom discipline but does affect teacher-student relationship. Therefore the study recommended that Teacher's personality should be one of the criteria in the employment of teachers by employers of such labour apart from educational qualification and Personality influences. The behaviour of the teacher should be checked in diverse ways, such as interaction with students, teaching methods, and learning experience chosen. The teacher should ensure that his personality speaks positively to the students in encouraging them to learn in tertiary institutions in Nigeria.

\section{References}

Andabai, P. W. (2010). Learning, Organizational Learning and the Learning Organization: Concept, Theories and Models. Journal of Knowledge Management. Vol.1 (2).Pp. 34-42.

Andabai, P. W. (2010). The Impact of Teaching Practice on Trainee Teachers in the Nigerian Tertiary Institutions: The Niger Delta University Experience. Vol. 8(2). pp. 24-42.

Achuonye, K. A. and Ajoku, L.I. (2003). Foundations of curriculum: Development and Implementation. Port Harcourt. Pearl Publishers.

Awotua-Efebo E. B. (1999). Effective Teaching: Principles and Practice. Paragraghics.

Coats, W. D. (1977). Student Perceptions of Teacher: A factor Analytic Study. Paper presented the American Educational Research Association convention, Cited in W. J ones \&

Common, R. (2004). Organizational learning in a Political Environment: Improving Policy-Making in UK Government. Policy studies, Vol. 25(1). Pp. 34-45.

Eribo, F. (1996). Higher Education in Nigeria: Decades of Development and Decline. A J ournal of Opinion, Vol. 42 (18) Pp.138-143.

Hassan, Bello (2006). Qualitative Technical Teacher Education as a Strategy for Technology Development. International Journal Social and Policy Issues. Vol. 4 (1\&2).

Imart, J. (2003). Two Basic Mechanisms for Organizational Learning in Schools. European Journal of Teacher Education, Vol. 36, No. 3.

Jacob A. A, and Herma, J. L. (2009) "Psychoanalysis." Microsoft Encarta (DVD). Redmond, W. A: Microsoft Corporation.

Johnson, R. (1994). Open Learning: Policy and Practice. National Board of Employment, Education and Training Commission. Report Canberra Australian Government Publishing Services. Vol. 6, No. 4.

Koko, M. N. (2000). Foundations of Business Education, Port Harcourt: Pre J oe Publishers.

Kizlik R. (2007) Classroom Management. Retrieve 20 ${ }^{\text {th }}$ February,

Koko, M. N. (2001). Teaching Business: Method and Procedure. Besthand Publishers. Owerri.

Kim, D. C. (1993). The Link Between Individual and Organization Learning. Solan Management Review Vol. 38 (16).pp 44-55.

Kpeke, E. E. (1992). Is Teaching a Profession? In V.F. Peretomode (Ed). Introduction to Teaching Profession in Nigeria. Owerri.

Kizlik R. (2007) Classroom Management. Retrieve 20 ${ }^{\text {th }}$ February,

Koko M. N. (2002). Organizational Behaviour: concept and dimension. Bengray Publishing Company. Port Harcourt.

Lew, W.J.F (2009). Teaching and Teacher Personality. Retrieve $2^{\text {nd }}$ January.

Lumsden, Linda (2009). Student Motivation to Learn. ERIC Digest, Number 92. S. Retrieved $2^{\text {nd }}$ J anuary. 
Mkpandiok, A. A. (2006). National Policy on Education in the Light of the Four Policy Conditions in Nigeria. International J ournal of Social and Policy Issues. Vol. 4 (1\&2).

Osakwe, E. O. and Okoye, N. S. (1998). The Teaching Learning Process: In Inomiesa, E. A. and Osakwe, E. O. (Ed) Principle and Practice of Teaching. Warri. Abou Research publishers.

Rodriquez, L. (2008). Classroom Management. Retrieved $20^{\text {th }}$ February. 